\title{
Sinema-Mimarlık Arakesitinde Cyberpunk (Siberpunk) ve "Ada" Filmi Üzerinden Eleştirel Bir Yaklaşım
}

\author{
Sonay AYYILDIZ ${ }^{1 *}$, Senem MÜŞTAK²
}

\section{Öz}

Mekan, mimarlık-sinema arakesitinde yer alan ve her iki disiplinin de temelini oluşturan bir kavramdır. Sinema için bir oyuncu kadar etkili sayılabilecek sinemasal mekan, mimarlıkta insan yaşamını örgütleyen ve onu anlamlandıran bir unsurdur. Diğer türlerden farklı olarak bilimkurgu sineması, mekan tasvirlerinin günümüzden radikal bir şekilde farklılaştığı ütopik veya distopik gelecek öngörülerini sunmaktadır. 1980'lerle birlikte dünyada hızla gelişen teknoloji, bilimkurgu sinemasını da temelden etkileyerek yeni bir alt dalı olan Cyberpunk akımı ortaya çıkmıştır. Cyberpunk, sanayi sonrası modern toplumlarda yaşanan temel değişimlere eleştirel bir yaklaşım sunarken yakın gelecek öngörülerini, ileri teknoloji, sefil hayat, kaotik dünya konularını işlemekte ve kendi kurgusal mekanlarını üretmektedir. Michael Bay yönetmenliğindeki "Ada" filmi Bilimkurgu sinemasında Cyberpunk akımı içerisinde güncel filmler arasında önemli bir yere sahiptir. Film, beden üzerinden insanın bile metalaştırılabileceğini ve büyük şirketlerin elinde nasıl kontrol edilerek şekillendirilebileceğini gösteren karamsar bir senaryoyla kapitalizm eleştirisi yapmaktadır. 2005 Yapımı film, 2019 yılına distopik bir yakın gelecek öngörüsünde bullunmaktadır. Filmde, toplumun üst gelir grubu bireylerinin toplum üzerinde etkilerinin devam edebilmesi için her türlü sosyal ve etik değeri göz ardı ederek insan klonlamayı yasal hale getirmeleri ve bu klonları insan olarak değil ürün olarak nitelendirmeleri söz konusudur. Filmdeki kişisel, yarı kamusal ve kamusal mekanlar fiziksel ve psikolojik olarak tek tipleştirilmiş iktidar gözetiminde tutulan mekanlardır. Bu bağlamda çalışmanın amacı, bilimkurgu sineması alt kültürü olarak cyberpunk'ta zaman, mekan ve beden kavramlarının mimarlık sinema arakesitinde Ada (The Island) filmi üzerinden tartışılarak değerlendirilmesidir.

Anahtar Kelimeler: Mimarlık, Sinema, Bilimkurgu, Distopya, Cyberpunk

\section{A Critical Approach over "The Island" Movie and Cyberpunk in Cinema-Architecture Intersection}

\begin{abstract}
Space is a concept which takes place in architecture-cinema intersection and which is a base for both of the disciplines. Cinematic space, which can be counted as important as an actor for cimema, is an element in architecture which organizes human life and makes it meaningful. Different from other types, Science fiction cinema presents utopic and dystopic future foresights which differs radically from today's modern description. Improving technology starting from 1980s has introduced a sub-branch called Cyberpunk by affecting the science fiction cinema base. Cyberpunk while presenting a critical approach to basic changes faced in the modern public, discusses the near future foresight, hi-tech, miserable life, chaotic world subjects and creates its own spaces. "The Island" movie directed by Michael Bay has an important place among the contemporary movies having Cyberpunk movement in science fiction cinema. Movie criticizes capitalism with a pessimistic scenario in which it shows even human body can be commodified from his body and how he can be shaped with a control of giant companies. Movie of 2005 makes dystopic near future foresight to 2019. In the movie, legalizing human cloning by ignoring the social and ethical values for continuation of the individuals of high income group's effects on public and identifying these clons as a product not a human are the points in question. Personal, public and semi-public spaces in the movies are the spaces which were stereotyped physically and psychologically and under observance of the government. In this concept, the aim of the study is to evaluate by discussing the concepts of time, space and body in Cyberpunk as a sub-culture according to "The Island" movie in architecture and cinema intersection.
\end{abstract}

Key Words: Architecture, Cinema, Science Fiction, Distopia, Cyberpunk

\footnotetext{
${ }^{1}$ Kocaeli Üniversitesi, Mimarlık ve Tasarım Fakültesi, Mimarlık Bölümü, sonayayyildiz@gmail.com

${ }^{2}$ Kocaeli Üniversitesi, Mimarlık ve Tasarım Fakültesi, Mimarlık Bölümü *ilgili yazar / Corresponding author: Sonay AYYILDIZ, sonayayyildiz@gmail.com Gönderim Tarihi: 07.12.2016

Kabul Tarihi: 20.12 .2016
} 
"Sinema, geldi ve zindandan oluşma bu dünyayı saniyenin onda biri uzunluğundaki zaman parçacıklarının dinamitiyle paramparça etti; şimdi bu dünyanın geniş bir alana dağılmış yıkıntıları arasında serüvenli yolculuklara çıkmaktayız."

Walter Benjamin

\section{GiRiş}

Tarih boyunca bilim, sanat ve felsefe hep birbirleriyle etkileşim içerisinde olmuşlardır. 19. Yüzyılın sonunda Endüstri Devrimi sonrası artan bilgiyle disiplinler özelleşmeye başlamıştır. Mimarlık disiplini; tasarım, kentsel planlama, tarih, sanat, felsefe, arkeoloji, teknoloji ve politika gibi alanlarla ilişkilenmiş ve zamanla teori ve pratikte farklı disiplinlerle oluşturulan bu ara kesitler çoğalmıştır. 19. yüzyılda sinemanın icadı ile mimarlığın ilişki kurduğu yeni bir disiplin daha ortaya çıkmıştır. Anthony Vidler'e göre tüm sanatlar içinde mimarlık film ile en ayrıcalıklı ve zor ilişkiyi kurmaktadır (Dear, 1994, s.8-15). Günümüze kadar gelen süreçte, sinema ve mimarlık birbirleriyle çok fazla ortak etki alanı bularak kendi tekniklerini oluşturmuş ve yeni üretimlerde bulunmuştur. Sinema'nın kendisini belli formlarda yeniden üreten bir parçası da, alternatif bir zaman-mekan ilişkisinde yeni görme biçimlerine olanak sağlıyor olmasıdır (Süalp, 2004, s.22).

İnsan doğumundan itibaren mekan ile çevrelenmekte ve mekansız var olamamaktadır. Merleau-Ponty'nin söylemiyle "varoluş mekansaldır" (Merleau-Ponty, 1962, s.22). Tümer'e göre (1984) ise, varoluş yalnızca maddesel yönüyle değil ruhsal yönüyle de mekânsaldır. Mekan kavramı, mimarlık ve sinema arakesitinde iki disiplinin de temelini oluşturmaktadır. Her filmin belirli bir kurgusal sinematik mekanda geçtiğini de göz önüne alırsak; mekan, kimisinde arka fon olarak, kimisinde kurguyu tamamlayan bir öğe olarak kimisinde ise kurguyu oluşturan temel öğe olarak yer almaktadır. Mimarlık gerçek dünyada gerçek mekanlarını üretirken, sinemada bu mekanların yapay temsillerini üretmektedir. Diğer türlerden farklı olarak bilimkurgu sinemasında, üretilen mekanların günümüz mekanlarından radikal bir şekilde farklılaşan ütopik veya distopik gelecek kurgularını yansıttığı görülür. Bilimkurgu filmleri için bilgisayar ürünü mimarlık, yapı ve kent imgelerinin yaratıldığı, bazen de fütüristik mekanlar olarak değerlendirilen belirli yapıların kullanıldığı görülmektedir (Kırış, 2012, s.190).

İleri sanayi ve teknoloji toplumlarında, insan-teknoloji-toplum ilişkisinin yaşanılan zamana ait olarak ortaya çıkan beklenti veya korku noktalarını bu üretilen sine-mekan kurgularında tanımlar. Böylece gelecek algısı alternatif bir bakış açısıyla vurgulanır. Dünyada hızla gelişen teknoloji Bilimkurgu Sineması'nı da temelden etkilemiş ve yeni bir alt dal olarak Cyberpunk akımını ortaya çıkarmıştır. Cyberpunk; sanayi sonrası modern toplumlarda yaşanan temel değişimlere eleştirel bir yaklaşım sunarken yakın gelecek öngörülerinde ileri teknoloji, sefil hayat, kaotik dünya konularını işlemekte ve kendi distopik dünyasında insanlığı karanlık bir yaşantıyla özdeşleştirmektedir. Cyberpunk sınırsız düş gücüne sahip zihnin, sınırlarla çevrili olan bedenle hesaplaşmasının bir ürünüdür. Yaşam içgüdüsü aracılığıyla bedenin zayıflığına ve ölüme karşı direnişin dışavurumudur.

Çalışmanın amacı; "Distopik Sinema-Mimarlık" arakesitinin, bilimkurgu sineması alt dalı olarak cyberpunk filmlerinden Michael Bay yönetmenliğindeki "Ada" filmi üzerinden karamsar bir gelecek öngörüsünde kapitalizm eleştirisi yaparak zaman, mekan ve beden kavramları üzerinden değerlendirilmesidir. 


\section{BILIMKURGU SINEMASINDA ÜTOPYA, DISTOPYA VE MIMARLIK}

Sinemanın keşfedilmesi ile zamansal ve mekânsal algıda tanık olunan dönüşümler içerisinde mimarlık ve sinema arasında benzerlikler vardır (Örs, 2001, s.73). Filmlerde mekânsal tasarım yakından incelenmişse de mimarlık ve şehrin filmlerden nasıl etkilendiği yeterince çalışılmamıştır. Mimarlar, ilham kaynakları olan filmler üzerine yorumlar yapmışlar, ancak sinema mimarlardan çok daha geniş bir kitleye ulaştığından onların da mimarığa bakışlarını ve beklentilerini şekillendirmektedir. Özellikle bilimkurgu sinemasında ütopik veya distopik kurgular bu bağlamda önemli bir yer tutar.

Ütopya genellikle yok-mekan, olmayan yer, hayali yer, yeryüzü cenneti, ideal yer, ideal kent gibi kavramlarla tanımlanır. Ütopya dendiğinde insan aklına ilk gelen şey hayali de olsa bir çevre, yer, mekân ya da kenttir. Mekân hayatı önceliğe alan ütopyanın vazgeçilmez bir unsurudur (Alver, 2009, s.140).

Ütopya didaktiktir, herkes tarafından kabul görmüş çözümleri önermektedir. Ütopyada toplum, her şeyin planlandığı kapalı bir dünyadır. Karşı çıkmanın ve düzensizliğin korkusu hakimdir. Ütopik düzen, dağılmanın yersizliğine karşı yeri ve tutkuya karşı intiyaçları önemsemektedir. Kolektif kaynaşmanın arayışı içindedir. Bunun içindir ki ütopya genellikle bir ada ya da kapalı, sınırları belirgin bir şehirde kendini var etmektedir. Zamansal olarak baktığımızda bu mekân tasarımı zamansız, ebedi, değişimi içeren bir zamanlar bütünüdür. Ütopya kusurun ölümüdür (Ülker, 2011, s.30).

Ütopyalar, yalnızca hayal edilen ideal toplum arayışları olmayıp gelecekte tasarlanan kentsel yapıları, kentsel yaşam biçimlerini ve kent planlarını da ciddi biçimde etkilemişlerdir. Bu nedenle ütopyalar, yalnızca zamanın hayalleri değil, geleceğin gerçekleri olarak da görülmelidir. Ütopyalar, geleceği bugünle ilintili ama bugünün ötesine geçen iyimser bir tarzda inşa ederken, karşı ütopyalar (distopyalar) geleceği bugünün bir yansıması ve daha karamsar bir şekilde inşa eder (Ülker, 2011, s.41). Özellikle 20. yüzyıldan başlayarak gelişen distopya yazınının ana sorunsalı, devletin birey üzerinde mutlak bir otorite sahibi olduğu totaliter devlet sistemleridir.

20. yüzyılın ikinci yarısından itibaren modernizme duyulan tepkiler kendini postmodern sanat anlayışında yoğunlaşarak göstermeye başlamış ve bu dönemde özellikle distopik kurgular kendini yeni bir söylemle sergilemeye başlamıştır. Distopyanın postmodernizm açısından önemi, kötü koşulları ve bireyin psikolojik durumunu irdeleyebilmesidir (Polat, 2012, s.55). 20. yüzyılın ikinci yarısından sonra ütopyalardan çok distopyaların ortaya çıkması, kentin de distopyaların mekanı olmaya başlaması açısından dikkat çekicidir. İnsan üzerinde uygulanan baskı aracılığıyla yönetimin devamını sağlamayı amaçlamaktadırlar. Distopyalarda denetim dışarıdan mimari araçlarla da yapılır. "1984" adlı filmdeki gibi sokaklar ve işyerleri hatta evler devletin sürekli dinleme ve izlemesine olanak sağlayan teknolojik aygıtlarla donatılmaktadır.

Distopya mutluluğun, sadece elitlere ve karşı çıkmayan sosyal sınıflara rezerve edildiği bir düzeni işaret etmektedir. Böylece distopistler ütopyalardaki gerçekleşmesi mümkün olmayan idealleri yergi, eleştiri ve ironi sanatını kullanarak çürütüp gerçekleri kendine özgü çeşitli yollarla göstermeye çalışır. Distopyada toplumsal ve kültürel öğeler, iş bölümü ve farklılaşma ütopyada olduğu gibi devletin denetimindedir. Bireylere düşen görev kurallara boyun eğmektir. Eğer toplum içinde mevcut düzen anlayışına bir tepki ortaya çıkarsa, devlet bunu baskıyla ortadan kaldırır. Distopyaların çıkış kaynağını bu baskılar oluşturur. Farklı sınıflandırmalar aracılığıyla gözlemleyebileceğimiz ütopya kurgusu, sinema alanında edebiyatta olduğundan farklı olarak genellikle distopyayı da içinde barındıran göstergeler sunmaktadır. Distopik filmlerde de gücü elinde tutan 
teknolojik firmalar, kimliği belirsiz erkler aracılığıyla verilen iktidar söylemlerine karşı öfke ve kaos anlarında ortaya çıkan kurtuluş hikayeleri ve kurtarıcılar, bu iktidar savaşımlarının ardından kendi güçlerinin varlığını gösterme çabasındadır (Ülker, 2011, s.42).

Ütopya ve distopyalar bilimkurgu filmleri aracılığı ile sıkça izleyiciye sunulur. Bilimkurgu filmleri herkesin biraz korku biraz da merakla sorduğu "geleceğin dünyası acaba nasıl olacak?" sorusuna alternatif cevaplar üretirken aynı zamanda teknolojik gelişmenin ve ilerlemenin açıktan bir kritiğini yaparlar. Teknolojik gelişme, bilimkurgu filminde başta mekânsal olarak sembolize edilir. Tıpkı mimarlığın ürettiği ütopya projeleri gibi bilimkurgunun sunduğu imajlar da geleceğin mimarisi hakkında hayal gücünün sınırlarını zorlayan fikirler verir. Çoğu filmde "ideal gelecek" ile "kaçınılmaz son" birbirine karışır, gelecek, bir ütopya distopya çatışması çerçevesinde işlenir (Kınayoğlu, 2001, s.80).

Bilimkurgunun dünya yaratma süreciyle mimari tasarım arasında büyük bir benzerlik bulunmaktadır. Bilimkurgu sanatçısı ile mimarın temelde ortak yönleri, her ikisinin de tanrısal bir iş olan yeni dünyalar yaratmalarıdır. Göreceli olarak yeni bir tür sayılan bilimkurgunun kökeninde, insana özgü düşsel dünyalar hayal edebilme yeteneği yatmaktadır. Bilimkurgu özünde, günümüze özgü birtakım şeylerin gelecekte radikal biçimde değişeceği varsayımının yattığı deneysel bir yabancılaştırma sanatıdır (Özakın, 2001, s.82).

Bilimkurgu türü dendiğinde akla ilk uzay gemileri geliyorsa da, bilimkurgu için en uygun manzara kenttir. Kent aynı anda hem gerçeklik hem de simgedir; hem bir yaşam hem de bir düşünüş tarzıdır. Bütünüyle tasarlanmış, tutarlı bilimkurgu kentiyle ilk defa Metropolis (1927) filminde tanışıldı. 1980'lerle birlikte kıyamet mitinin bilimkurgu aracılığıyla yaşantımıza geri dönüşüne tanık olduk. Mimarlık bünyesindeki mitleri çözümlemek ve bunlardan kurtulmuş yeni alternatifler bulmak için bilimkurguyu bir araç olarak kullanabilir (Özakın, 2001, s.84-85).

1982 yılında Ridley Scott'ın Blade Runner filmi bir bilimkurgu ve kara film klasiği olarak anıırken, bu ürünün ardında, içinde dolanmaya başlayacağımız kenti hem fiziki hem de görsel tasarımlarla yeniden çizişi, film dilinin teknolojisindeki yeni ifadelerle anlatımsal alanda bireysel, kamusal ve toplumsal alanda karşılaşacağımız çatışma ve çelişki sorularını iyi bir seyirliğin içinde sunabilmesi ve geleceğe ait öngörüsü yatmaktadır (Süalp, 2004, s.77).

\subsection{Distopya'da Cyberpunk (Siberpunk) Kavramı}

İletişim, kontrol, hız ve haz çağı olarak nitelendirilen 20. Yüzyıl, gelişen teknolojiyle beraber insan hayatını her geçen gün daha fazla etkilemeye ve bilim, sanat, edebiyat alanlarında daha fazla etki alanı bulmaya başlamıştır. Bu bağlamda, yüksek teknolojiye vurgu yapan "cyber" sözcüğü ile, yasadışıı̆̆ı, asiliği ve sokak tarzı bir yaşamı vurgulayan "punk" sözcüklerinin bir araya gelmesiyle birlikte yeni bir bilimkurgu alt dalı 80'lerde kendini göstermeye başladı : “Cyberpunk”. İnanılmaz ölçüde karmaşık ve tuhaf bir gelecek fikirlerinden üretim alanı bulan bilimkurgu hareketi olan Cyberpunk, dev iletişim ağlarıyla örülmüş küresel bir köye dönüşen dünya tasvirlerini bizlere sunar (Ersümer, 2013, s.17).

Cyberpunk, 1970'lerde sanayi sonrası modern toplumlarda yaşanan temel değişimlere ayna tutar niteliktedir. Dönemin sosyal, ekonomik, kültürel, politik, teknolojik 
gelişmeleriyle beslenir ve yakın gelecek öngörülerinde bulunur. Fredric Jameson'a göre Cyberpunk; "Çoğumuz için postmodernizmin olmasa bile, geç kapitalizmin en üstün yazınsal ifadesi” dir (Jameson, 1994, s.24).

Cyberpunk bir teknoloji aşığı (teknofiliyak) veya bir teknoloji korkağı (teknofobik) olmadan teknolojiyle birlikte yol alsa da onunla tamamen bütünleşmedi. 80 'ler boyunca dünya çapında büyük ses getiren yazınlar kaleme alındı ve filmler gösterime girdi. Çok yeni çağdaş bir tarz olarak cyberpunk, bu süreçte değişti, gelişti ve çokça mutasyonlar geçirdi. Cyberpunk başyapıtı olarak nitelendirilen William Gibson (2012) eseri Neuromancer'ın basıldığı yıl olan 1984 'te, IBM firması ilk kişisel bilgisayarı, Motorola firması Amerika'da ilk cep telefonunu, Sony firması ilk kamerayı dünyaya tanıtmış ve ilk kompakt disk tasarlanmıştı. Yine 1982 yapımı cyberpunk hareketinin başyapıtlarından diğeri olarak ele alınabilecek eser de Ridley Scott yönetmenliğindeki Blade Runner filmidir. Filmde ileri teknoloji ve sefil hayat vurgusu yapılarak aslında sokağın teknolojiyi kendine göre kullanma yolları betimlenmiştir. Filmde insanlar hala insandır, bedende teknolojik bir dönüşüm süreci yaşanmamıştır ancak düşünüp hissedebilen "İnsandan daha insan" olarak tariflenen androidler teknolojinin ve dünyanın geldiği noktayı sorgulatır. 2019 yılının distopik bir tasfirini gördüğümüz filmin çekildiği 1980lerde yapay organ üretimine başlanması ve bu organların insan vücuduna nakledilmesi, DNA'nın daha geniş kullanım alanlarına yayılması ve ilk insan genom projesinin başlatılması gibi gelişmeler film senaryosunun ve gerçek hayatın eş zamanlı etkileşimini gözler önüne sermektedir. Filmde kent yaşamında göze çarpan karmaşa ve umutsuzluk, 70'lerden beri süregelen ekonomik kriz ve işsizliğin neden olduğu "Gelecek yok" düşüncesine sahip gençlerin kurduğu gelecek tahayyülünün ta kendisini yansıtmaktadır. Cyberpunk ve Punk kavramlarının kesişimini yaratan bu düşünce, hiçbir şeyin kalıcı olmadığı, kaos gününün kurtuluş günü olacağı, ölüm ve yaşamın çarpıştığı en kuvvetli çelişkileri kendinde barındıran bir düşünce hareketidir. Bozulma, karşıtık, çaresizlik, korku, kararsızlık, zulüm, gizlilik, dehşet, paranoya gibi kavramlar Blade Runner örneğinde de olduğu gibi cyberpunkın distopik konu motiflerini oluşturmakta ve bu bahsedilen kaotik dünya tasvirini destekleyen bir dünya yaratmaktadır.

Hemen her cyberpunk eserinde istila, çöküş ve bozulma dışarıdan gerçekleşen bir olgudur. Genellikle güç kullanımının kaynağı, hataya düşebilen insanoğlundan daha üstün bir varlık arzulayan çokuluslu kapitalizmdir (URL-1, Istvan Csicsery - Ronay, Jr, 1996). Sterling'e (1988) göre, Cyberpunk olarak nitelendirilebilen eserlerde bedenin saldırıya uğrayışı (istila) teması: protez organlar, vücuda yerleştirilen devreler, kozmetik cerrahi, genetik değişimler olarak yer alırken, zihnin saldırıya uğrayışı (istila): beyinbilgisayar arayüzleri (interface), yapay zeka ve insan doğası ile benliği radikal şekilde yeniden tanımlayan nörokimya teknikleri olarak karşılık bulmaktadır (Ersümer, 2013, s.53). Elysium (Neill Blomkamp, 2013) filminde de gözlendiği üzere yakın gelecekte kurgulanan ileri teknoloji dünyasına karşılık, büyük kitlelerin sefil hayatlar sürdüğü görülmekte ve enformasyon çağının gereği olarak bilgi artık tanrısal bir güce ulaşmaktadır.

1990'dan itibaren hızını biraz olsun azaltan cyberpunk, kişisel bilgisayarların ve internetin git gide yaygınlaşması ve teknolojide meydana gelen gelişmelerle birlikte, cyberpunk izdüşümünde yeni yaklaşımlara olanak sağlamıştır. İlk web tarayıcının kullanıma açılması, ilk Windows arayüzünün (3.1) halka tanıtılması, İntel Pentium çipinin geliştirilmesiyle kişisel bilgisayarlarda yeni bir teknolojik döneme geçilmesi, Google ve Yahoo gibi günümüzde de hala varlığını sürdüren şirketlerin bilişim dünyasına adım atmasıyla 90'lı yıllar teknolojik açıdan büyük atılımların yapıldığı yıllar olmuştur. Gelişen teknolojinin bir yansıması olarak mevcut toplumsal düzende de farklılaşmalar meydana gelmiştir. Dönemin bilimkurgu temalarına bakıldığında yine 
bilişimin ön planda olduğu çoktan gerçekleşmiş bir sanal felaket ve bunun yarattığı çaresizlik ve toplumsal bozulmalar işlenmektir. Johhny Mnemonic (Robert Longo, 1995) ya da Gattaca (Andrew Niccol, 1997) filmlerindeki gibi bilim ve teknolojinin durmadan ilerlediği, sanayi ve teknolojinin küreselleşmiş şirketler tarafından yönetildiği, toplumsal kaosun hüküm sürdüğü bir dünya aslında 90'ların akademisyen ve bilim adamlarının yakın gelecek öngörülerinin distopik bir yansımasıydı. Teknolojinin getirdiği korku ve dehşetin bir diğer yansıması olarak Dark City (Alex Proyas, 1998) filminde ise bu yeni toplumsal kaosun sorgulanması, başka bir hayat arayışı, dış dünyanın sadece algılardan ibaret olduğu ve bunların zihnin bir ürünü olması gibi temalar işlenmektedir. Dönemin eserlerindeki ortak noktalar hepsinin büyük kent, dev kent veya küresel kent olarak adlandırılabilecek mekanlarda geçmesi ve aynı mekanları paylaşan çok sayıda farklı ulusun insanlarının küresel anlamda birbirine bağlı durumda olmasıdır. Gerçekliğin sürekli olarak yıkılıp yeniden inşaa edildiği, insanların bireysel kimliğine sabit olmayan, tüketilebilir, değiştirilebilir yeni statüler eklendiği bir tür gerçeküstü dünya tanımlanmaktadır.

2000'lerde ise 90'lardaki gibi teknolojiyle ilişkili konu motifleri daha baskın bir şekilde işlenmeye başlamıştır. 2000'lerin başından itibaren incelediğimizde; uzay ve teknoloji alanlarında önemli gelişmeler kaydedilirken, ekolojik ve küresel ekonomi alanlarında önemli kayıplar yaşanmıştır. Kişisel bilgisayarların $1 \mathrm{Ghz}$ hızını aşması, insan genom projesinin tamamlanması, beyinden ilk görsellerin elde edilmesi, internet kullanımının rekor seviyelere ulaşması ve insan kök hücresinin klonlanması gibi bilimsel ve teknolojik gelişmeler; uzaya ilk özel uçuşların gerçekleşmesi, bir çok ülkenin uzay araştırmalarına başlaması, gezici robotun Mars'a ayak basması ve Ay'da sıvı halde su bulunması gibi uzay araştırmaları film konularını belirleyici gelişmeler olarak yer almışlardır. Ekolojik alanda, Batı Afrika'da siyah gergedan neslinin tükenmesi, arktik denizinde buz seviyesinin minimum seviyeye ulaşması, Afrika nüfusunun 1 milyara ulaşması; ekonomik ve siyasal alanda ise küresel ekonomik krizler, Libya'da çıkan iç savaş, Tunus Hükümetinin ayaklanmalar sonucu düşmesi, yapılan nükleer anlaşmalar dönemin önemli gelişmeleri arasındadır. 1999-2003 yılları arasında 3 film olarak çekilen Matrix filmlerinde (Andy Wachowski, Lana Wachowski), bilgisayarlar ve insanlar arasındaki savaştan galip çıkan bilgisayarların kurduğu sanal gerçeklik dünyasında ileri teknolojiyle birlikte büyük kentlerin harabelere döndüğü, ekolojik dengenin bozulduğu, insanların yer altlarında makinelerden saklanarak yaşadıkları sefil hayatı gösteren distopik bir kurgudur. Bu yönleriyle tipik bir cyberpunk içeriği oluştururken, makinaların ele geçirdiği dünyada insanların çaresiz kalması metaforunda dönemin geçirdiği aşırı teknolojik yüklenme etkili olmuştur. Güneşin görülmediği ekolojik bozulmaların en yüksek seviyeye ulaştığı, kentlerin harabelere döndüğü ve insanların yer altlarına sığındığı dünya tasfiri ise ekolojik alandaki distopik öğeler olarak değerlendirilebilir. Dönemin cyberpunk detaylarını içeren bir diğer filmi ise Yapay Zeka'dır (Steven Spielberg, 2001). İnsan gibi davranan ve kendisinin de insan olduğuna inanan yapay zekaya sahip bir çocuğun, insan olmadığının farkına varmasıyla gerçeğe ulaşma yolculuğunu temel alan yapıtta yine distopik bir kurgu göze çarpmaktadır. Küresel ısınma sonucunda eriyen buzulların su seviyelerini yükseltmesi sonucu kıyı şehirleri sular altında kalmış, fakir ülkeler açlıkla boğuşurken, zengin ülkeler nüfusu kontrol altında tutmak için çocuk yapmayı sınırlandıran belirli kurallar getirmişlerdir. İnsan görünümlü yapay zekaya sahip robotlar hayatın bir parçası olmuşlardır. Ancak filmin genelinde zengin ülke örneği olarak ABD'ye yoğunlaşılmış ve karanlık, sefaletten çok refah düzeyi yüksek konforlu hayatlara sahip bir toplumsal çevre konu edilmiştir. 


\section{BİR CYBERPUNK ÖRNEĞI OLARAK ADA FILMINDE ZAMAN, MEKAN, BEDEN ELEŞTIRISI}

2005 yapımı Michael Bay'in yönettiği Ada (The Island) genetik biliminin bir konusu olan klonlama çalışmalarında kaydedilen gelişmelerin ışığında bir gün insanın bile metalaştırılabileceğine ve büyük şirketlerin elinde nasıl şekillendirileceğine dair karamsar bir senaryo sunmaktadır. Distopik sistem, klonlanma işlemlerinin yasal olarak izin verildiği 2019 yılının dünyasında kurulmaktadır. Politikacılar, sporcular, mankenler gibi toplumun elit kesimini oluşturan insanlar kendileri için bir anlamda "sigorta poliçesi" olması için kendilerini klonlatabilmektedirler. Bu oldukça pahalı bir işlem olması dolayısıyla sadece üst gelir grubuna ait kişilerin bu hizmetten yararlanmaları söz konusudur ve klonlarının varlığıyla toplumun elitleri ömürlerini, iktidarlarını olabildiğince uzatabilme şansına erişebilmektedirler. Bu durum haliyle sosyal eşitsizliğin ortaya çıkmasına yol açmaktadır (Başaran, 2007, s.162). Bu çalışmada filmin içeriği, postmodern kültürde sinema-mimarlık ara kesitinde zaman, mekan ve beden kavramları üzerinden değerlendirilmektedir.

\subsection{Zaman}

Zamanın içerisinde, bir geçmiş, bir şimdi ve bir gelecek barınmaktadır. Zaman, bir parçası daha önce var olmuş olan fakat artık ondan söz edilmeyen, diğer parçası ise var olmayan fakat var olacak olan ve bu iki parçanın arasında şimdinin yer aldığı üç parçalı bir bütün olarak da düşünülebilmektedir (Sütçü, 2005, s.56). Zamanın varlığı ancak önce ve sonranın kavranılmasıyla mümkün olacaktır. 2019 Yılının dünyasında geçen filmde klonların yaşantılarında bir standartlaştırma söz konusudur. Herkes belirlenmiş olan tek tip zaman çizelgesine göre hareket etmekte ve tek tip kıyafetler giymektedir. Ürün olarak tanımlanan klonların en fazla genç bir bireyin eğitimine sahip olmaları sağlanmaktadır. Günlük üretim hattı isleri ve eğlence faaliyetleriyle zihinleri meşgul edilen klonların dış dünyayı sorgulamayıp kendileri için kurulan düzenin getirdikleriyle oyalanmaları sağlanmaktadır.

Heidegger'e göre insan dünyada var olur; insanoğlu içinde yaşadığı dünyada var iken, bu dünyanın kurulumu da insanın kendi deneyiminden oluşmaktadır (Heidegger, 2008, s.54-65). Filmde, tüm klonlar için üretilen birbirinin benzeri ve gerçekliği olmayan anılar, klonların doğumlarıyla birlikte zihinlerine aktarılmaktadır. Klonların dış dünyaya kapalı bir mekanizma gibi çalışan mekanlarda yaşamalarıyla, gece-gündüz gibi doğal fiziksel zaman algısının olmadığı, şirket tarafından belirlenen yapay zamanlarla günlük yaşantılarını sürdürmelerine neden olmaktadır.

\subsection{Mekan}

Sinemada zaman imgesi ve hareket imgesinin göstergeleri aracılığıyla beden mekân ilişkisinde özne mekânsaldır. Farklı ölçeklerde mekân üretimleri görebileceğimiz sinema, geçmiş ve geleceği birleştirerek, zaman ve mekânı bu çerçevede bir araya getirmektedir. Sinemada aslında var olmayan mekan (non space) şimdiki zaman içerisinde yaşamaktadır (Ülker, 2011, s.24).

Filmin ana temasında da aslında var olmayan ütopik bir ada olgusunun vurgulanması dikkat çekicidir (Şekil 1.). Klonların gerçekliğinde bu ada, büyük felaketten etkilenmeyerek kurtulan dünyadaki tek doğa parçası olarak kalmıştır ve bu ütopik niteliğini sınırların kaldırıldığı özgür bir hayatın ancak burada yaşanacağı düşüncesinin yaratılmasıyla kazanmaktadır. Bu ortama gönderilmek için belirli dönemlerde düzenlenen çekilişleri kazanmak gerekmektedir ve her klon bu adaya gitmenin hayalini 
kurarak yasamaktadır. Filmde, klonların böyle doğal bir mekanın varlığına inandırılmasının amacı, aslında klonları ürün olarak kesilip kullanılacakları mekana gönüllü olarak gönderebilmek ve sistemin düzgün bir şekilde işlemesini sağlamaktır.

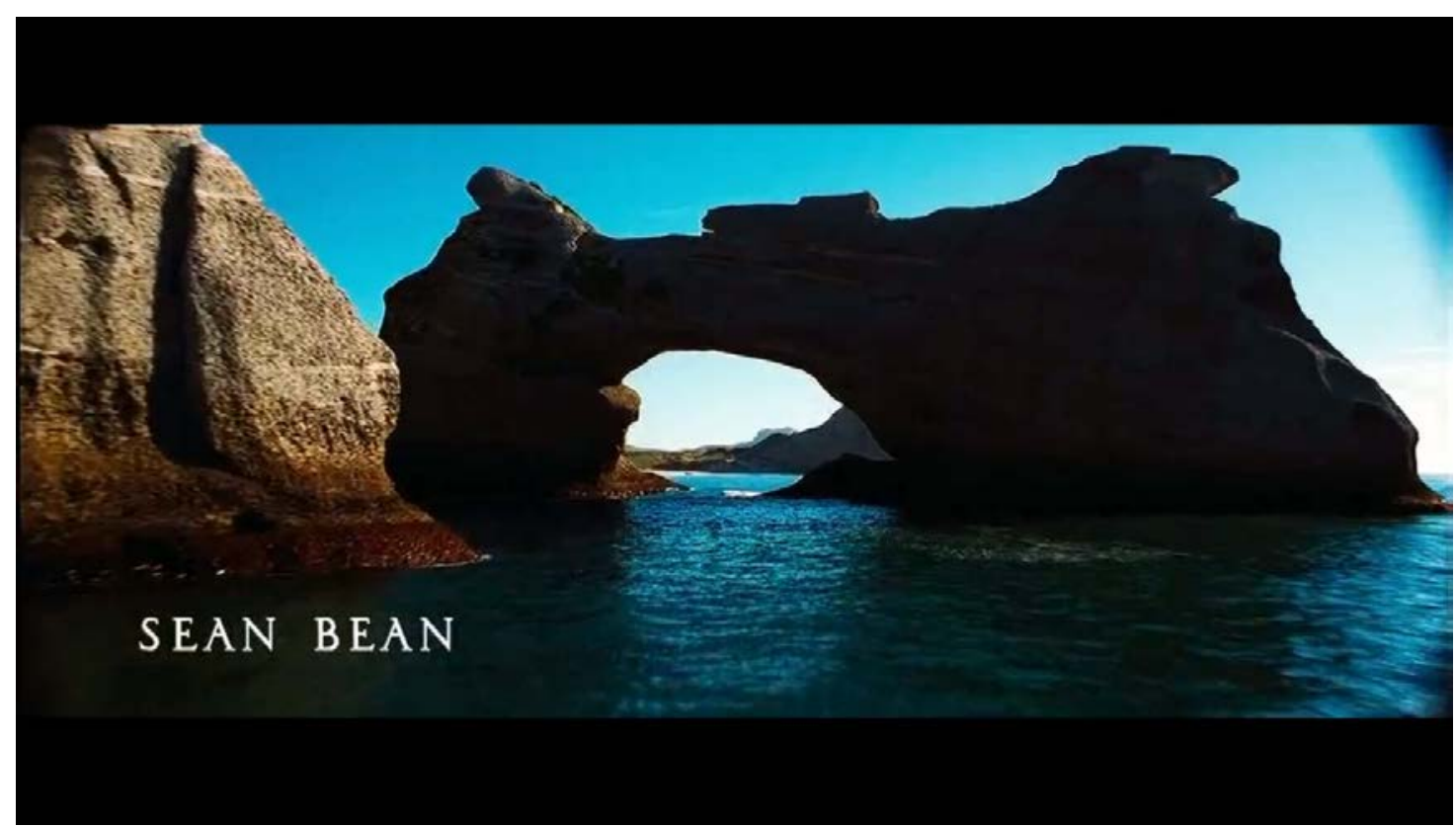

Şekil 1. Filmde Söz Edilen Ada (Bay, 2005)

Filmin geçtiği ana mekan olarak dairesel formda inşa edilmiş tesiste, her yer kameraların ve güvenlik görevlilerinin kontrolü altındadır. Bireylerin fiziksel temasları, günlük yaşamsal intiyaçları ve sosyal ilişkileri bu kontrol mekanizması ile sınırlandırılmaktadır. Bu durum bireyler (klonlar) üzerinde psikolojik bir baskı oluşturmaktadır.

Ana toplanma alanında çok sayıda ekran bulunmakta ve o ekranlar vasıtasıyla klonlara seslenilmektedir (Şekil 2.). Tüm mekanlarda göze çarpan detay, aydınlatma ve renk kullanımının sınırlandırılmış olmasıdır. Aydınlatmalar beyaz ve mavi tonlarda belirli noktaları ön plana çıkaracak şekilde düzenlenmiştir (Şekil 3.).

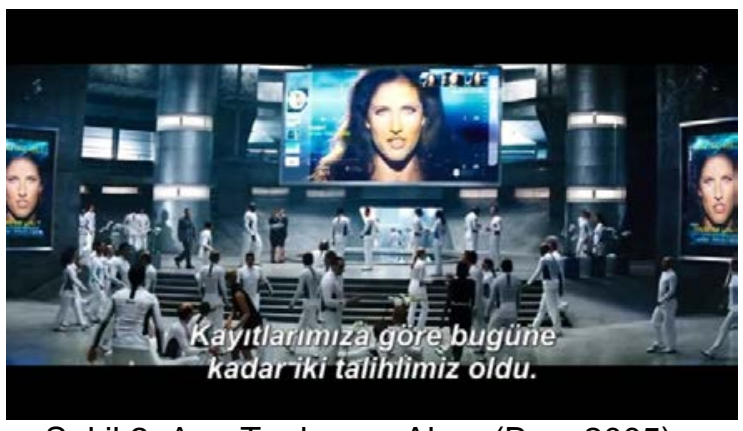

Şekil 2. Ana Toplanma Alanı (Bay, 2005)

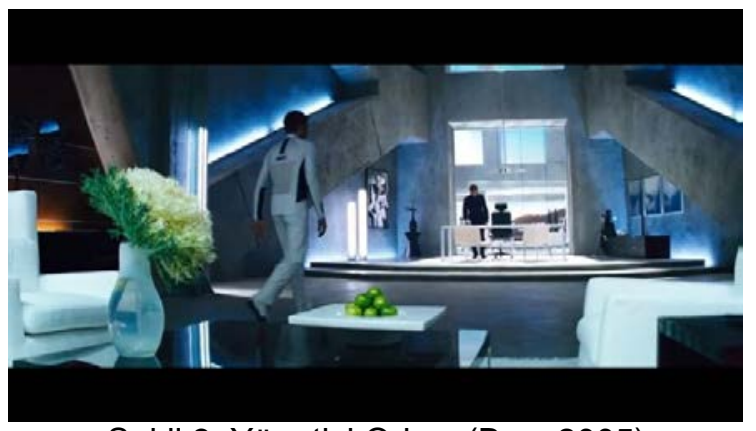

Şekil 3. Yönetici Odası (Bay, 2005)

Bu durum da yine mekanların ileri bir zaman diliminde, yüksek teknolojiyi yansıtan stabil mekanlar olmasına vurgu yapmaktadır. Ancak, iç mekanlarda kullanım amacı gözetilmeksizin brüt beton, cam, çelik gibi malzemelerle birbirine benzer ortamlar yaratılmıştır (Şekil 4-6). Sirkülasyon alanlarında bu malzeme kullanımları daha çok göze çarpmaktadır (Şekil 7). Filmdeki tüm mekanlarda, kullanıcı profili ve ihtiyaçları 
düşünülmeksizin mekansal öğelerde tek tipleştirme görülmektedir. Tesis içerisinde hiçbir yerde doğal ortam olmadığından iç mekan yüzeylerinde yapay doğa elemanları tasvir edilmiştir (Şekil 8).

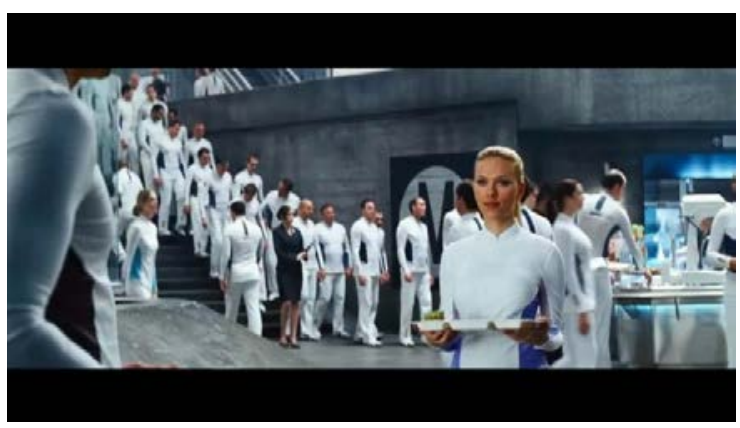

Şekil 4. Yemek Alanı (Bay, 2005)

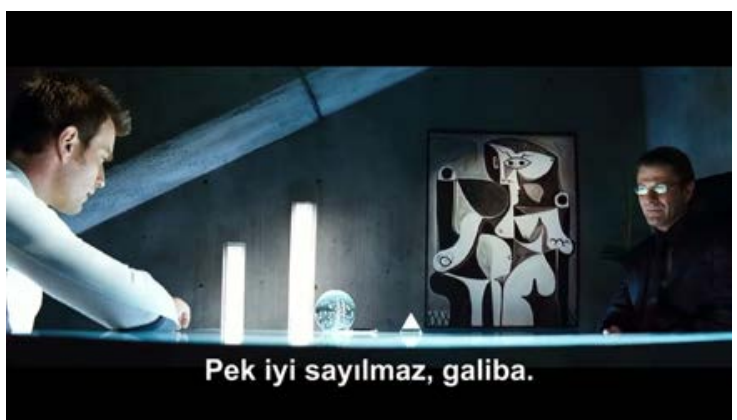

Şekil 6. Yönetici Odası (Bay,2005)

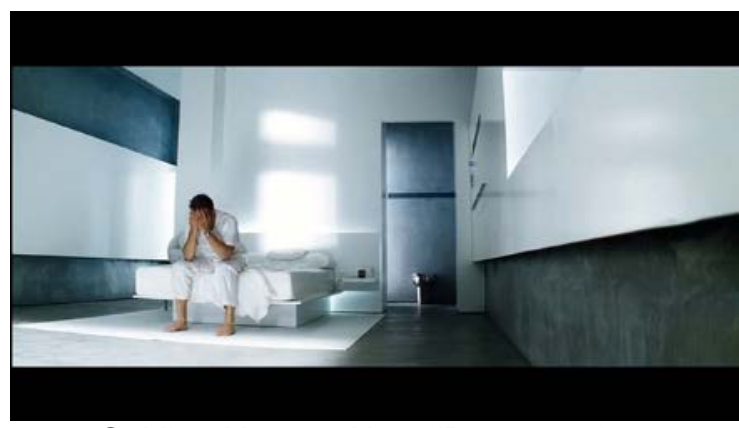

Şekil 5. Uyuma Alanı (Bay, 2005)

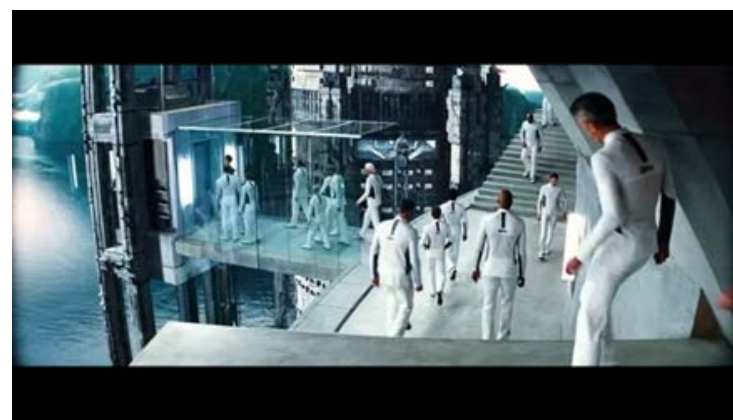

Şekil 7. Sirkülasyon Alanı (Bay, 2005)

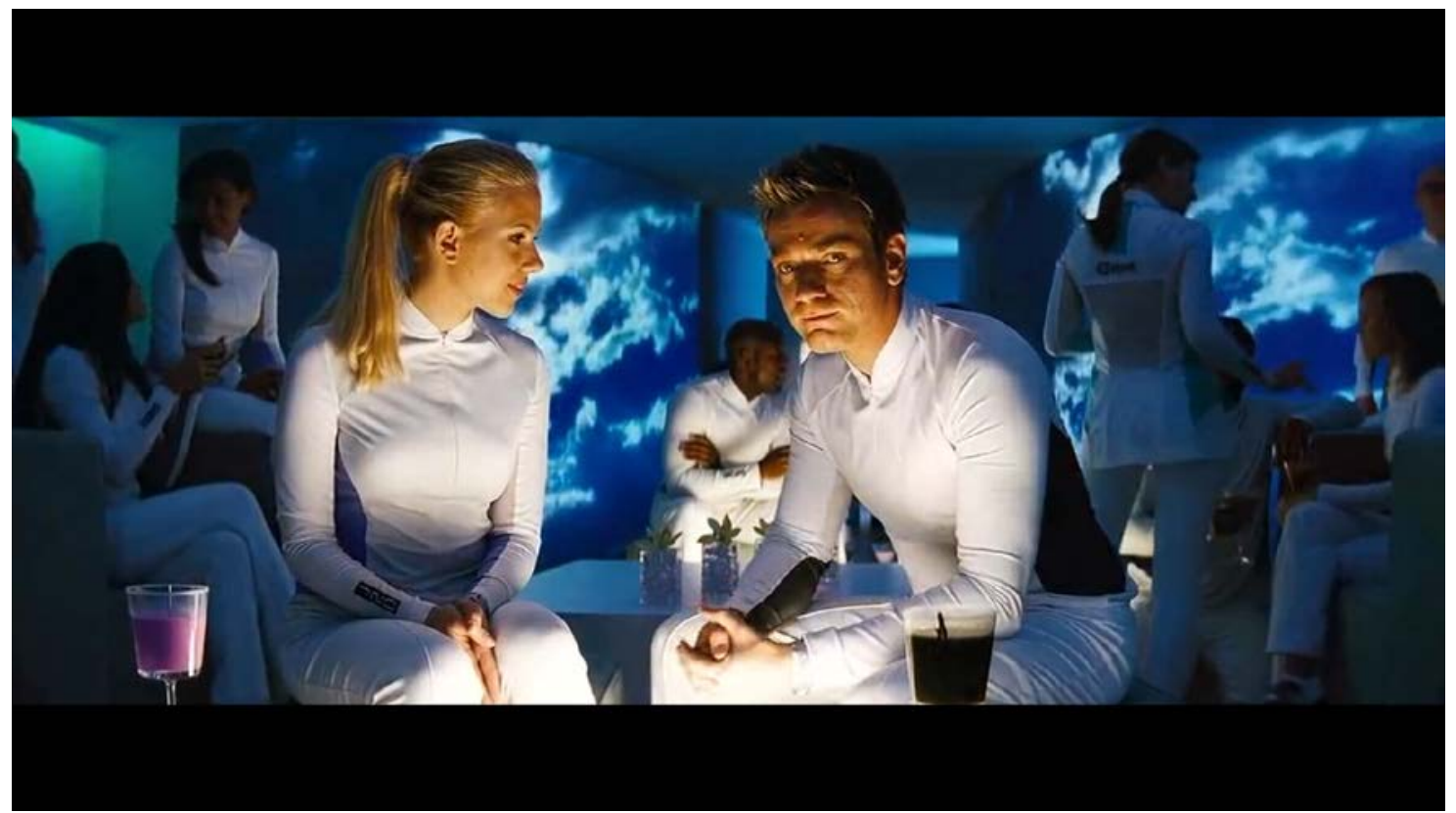

Şekil 8. Eğlence Mekanında Bulutların Yapay Tasviri (Bay, 2005)

Filmin son sahnelerinde görebildiğimiz dış dünya, 2019 yılına ait bir kent tasviri niteliğini taşımaktadır. Kent merkezinde yüksek yapılar, kirlenmiş ve kaotik bir kentsel mekan, havada farklı yüksekliklerde yapılar arasında giden tren hatları distopik bir kent imgesi yaratmaktadır (Şekil 9-11). 

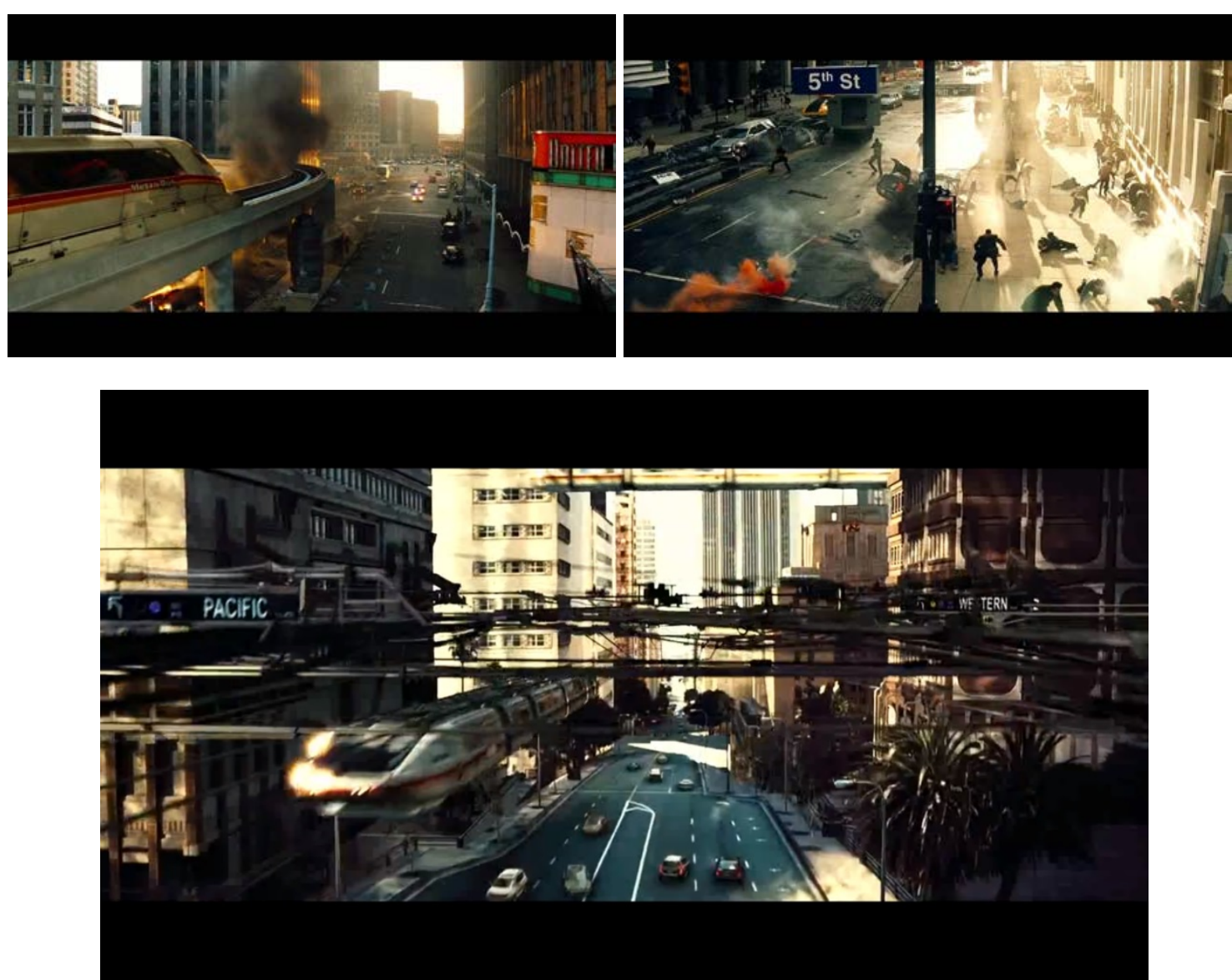

Şekil 9-11. 2019 Yılına Ait Kent Tasvirleri (Bay, 2005)

\subsection{Beden}

Ada filminde zihnin, gücün ve iktidarın devamı için insanın ölümlü bedeniyle olan hesaplaşması görülmektedir. Sonsuzluğa ulaşma, yaşama içgüdüsü ve buna karşılık bedenin zayıflığı ve sonluluğu ölüme karşı bir direniş oluşturulmasını gerekli kılmıştır. Filmin temasında toplumun üst gelir grubundan elit kesimi için mümkün olan bu ölümsüzlük kurgusu oluşturulan klonlarla sağlanmaktadır. Beden kavramı büyük şirketlerin elinde bir meta haline getirilerek kapitalizm etkisinde değersizleştirilmektedir (Şekil 12, 13).

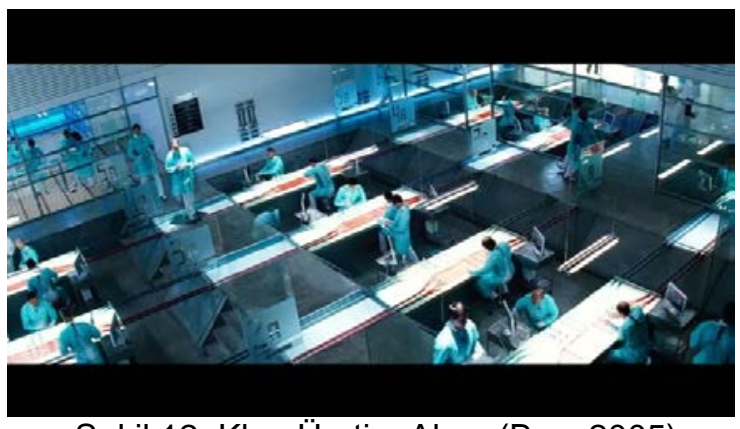

Şekil 12. Klon Üretim Alanı (Bay, 2005)

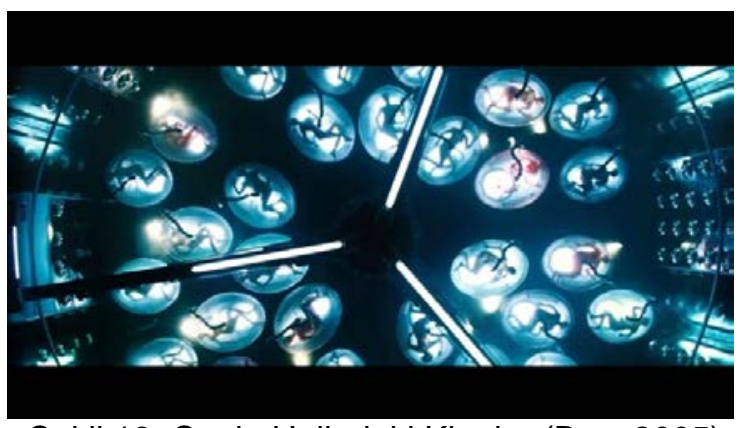

Şekil 13. Cenin Halindeki Klonlar (Bay, 2005)

Filmde klonlar zamanları geldiğinde, ya da başka bir deyişle sigorta poliçesi oldukları kişilerin organlarına intiyaç duyması halinde acımasızca kesilip biçilmeleri, şirketin onları birer sarf malzemesi seviyesine indirgemiş olduğunu açıkça göstermektedir (Şekil 14,15). Klonların isimlerinin bile, filmin kahramanları Lincoln-6-Echo ve Jordan-2- 
Delta'da olduğu gibi seri ve model numaralarından oluşmakta oluşu onların nasıl nesneleştirildiklerinin bir başka göstergesidir. Gözetim ve kurmaca gerçeklik teması, şirketin birkaç bin kişiden oluşan ürün stokunu yeraltında inşa edilmiş özel bir tesiste, kendi yarattığı gerçekliğinin yanılsamasıyla kontrol altında tutmakta oluşuyla ortaya çıkmaktadır (Şekil 16).

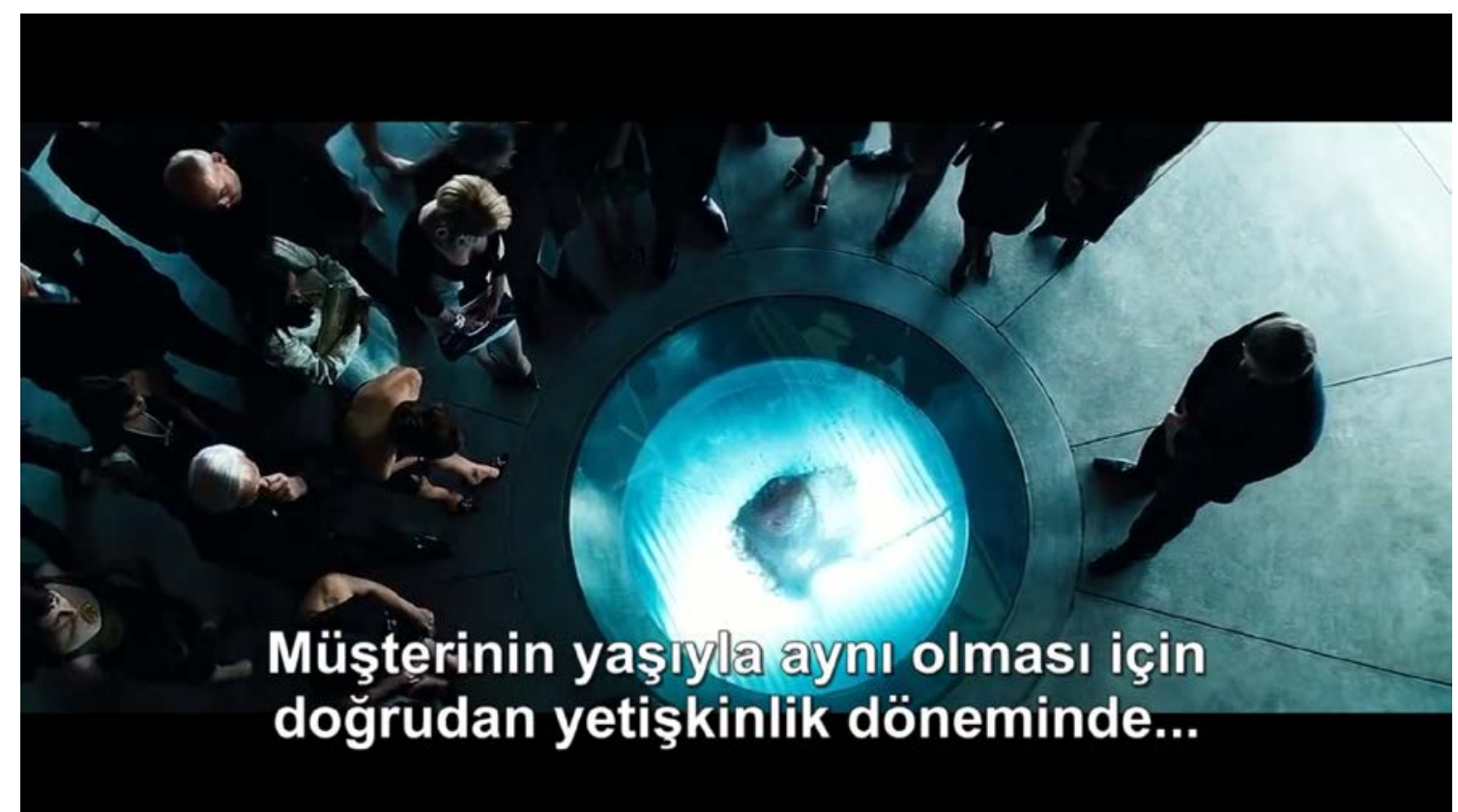

Şekil 14. Klonların Müşterilerine Tanıtım Anı (Bay, 2005)
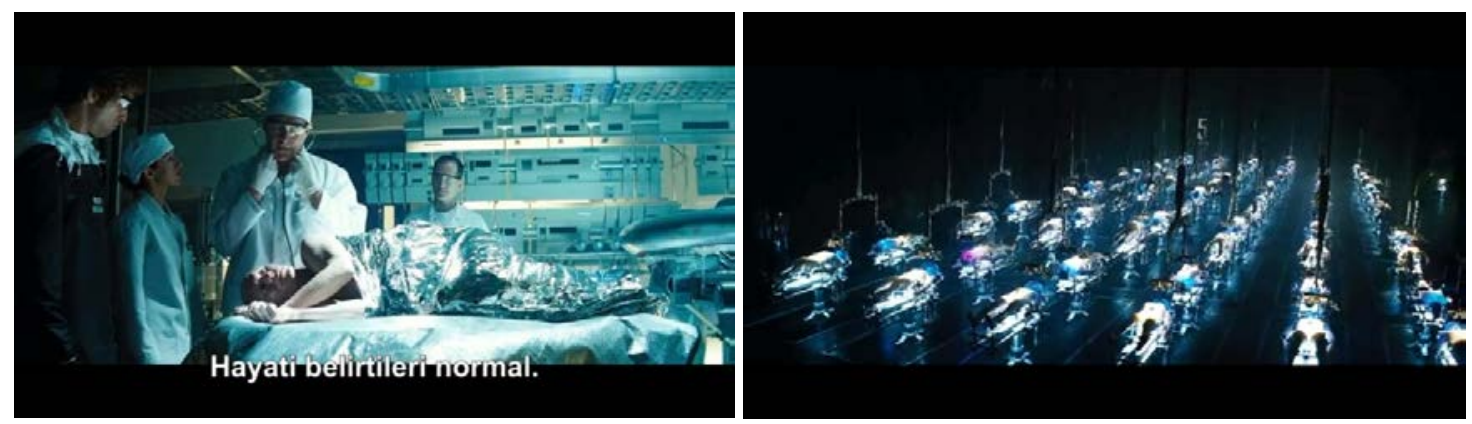

Şekil 15. Klonlardan Organların Alınması (Bay, 2005) Şekil 16. Klon Stok Alanı (Bay, 2005)

Klonların bilinçlerine birbirinin benzeri hikayeler kazınmakta, bu durum geçmişlerini sorgulamalarını engellemektedir. Tesis etrafında faaliyet gösteren dev projektörlerle fiziksel gerçeklikte de yanılsama yaratılarak bu durum desteklenmektedir.

Klonlar, tasvir edilen ada fikri kapsamında iktidarın onların iyiliği ve mutluluğunu gözettiğini (Şekil 17) düşünürken; klonlar kollarına yerleştirilen bilekliklerle bir denetim mekanizması altında, sahipleri ihtiyaç duyana kadar yaşatılmaktadır. Uyku halinde bile sistemin denetimi altında olan klonlar uyanmalarından itibaren sistemin gözetimi ve müdahaleleriyle karşılaşmaktadırlar; örneğin tuvaletlerde bile tahlil edilmektedirler ve diyetleri bu tahlillerin sonucuna göre belirlenmektedir. Öte yandan içinde yasadıkları gerçekliği sorgulamaya başlayan klonlar bedenlerine edilen müdahalelerle anında etkisiz hale getirilerek düzen devam ettirilmektedir (Şekil 18-20). 


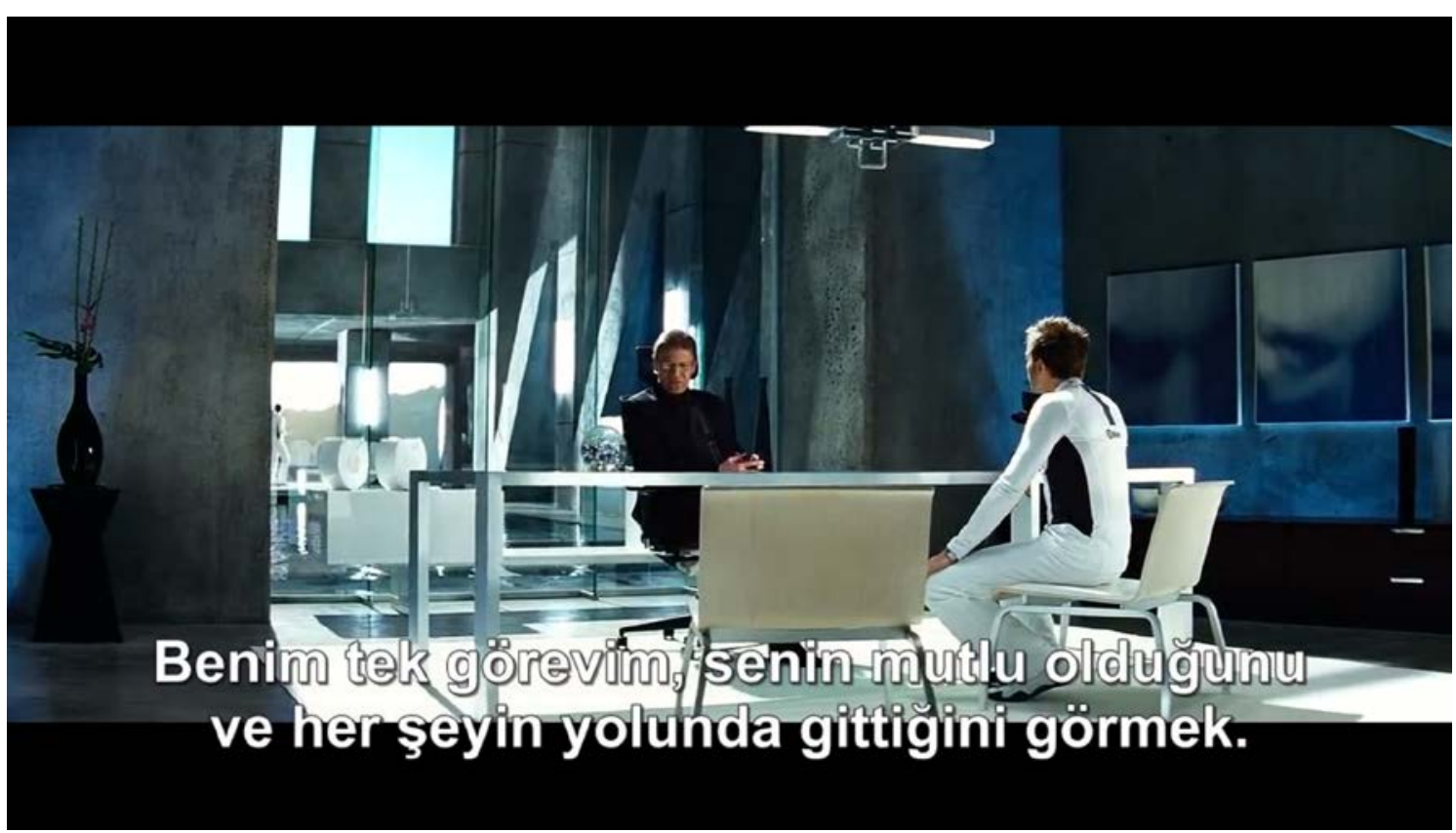

Şekil 17. Yönetici ve Klon Arasında Geçen Diyalog (Bay, 2005)
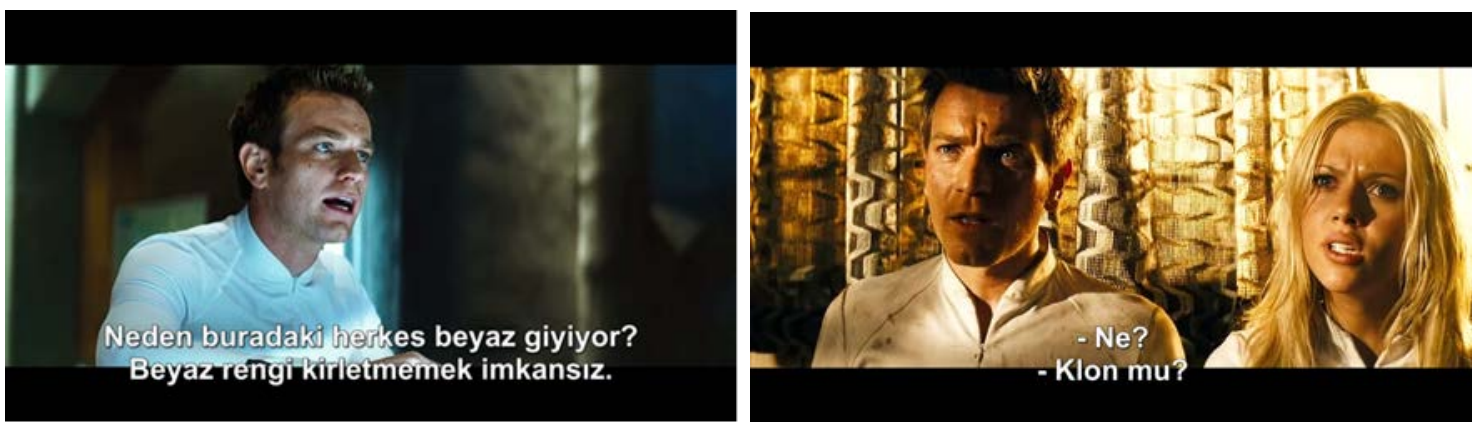

Şekil 18, 19. İçinde Yaşadıkları Gerçekliği Sorgulayan Klonlar (Bay, 2005)

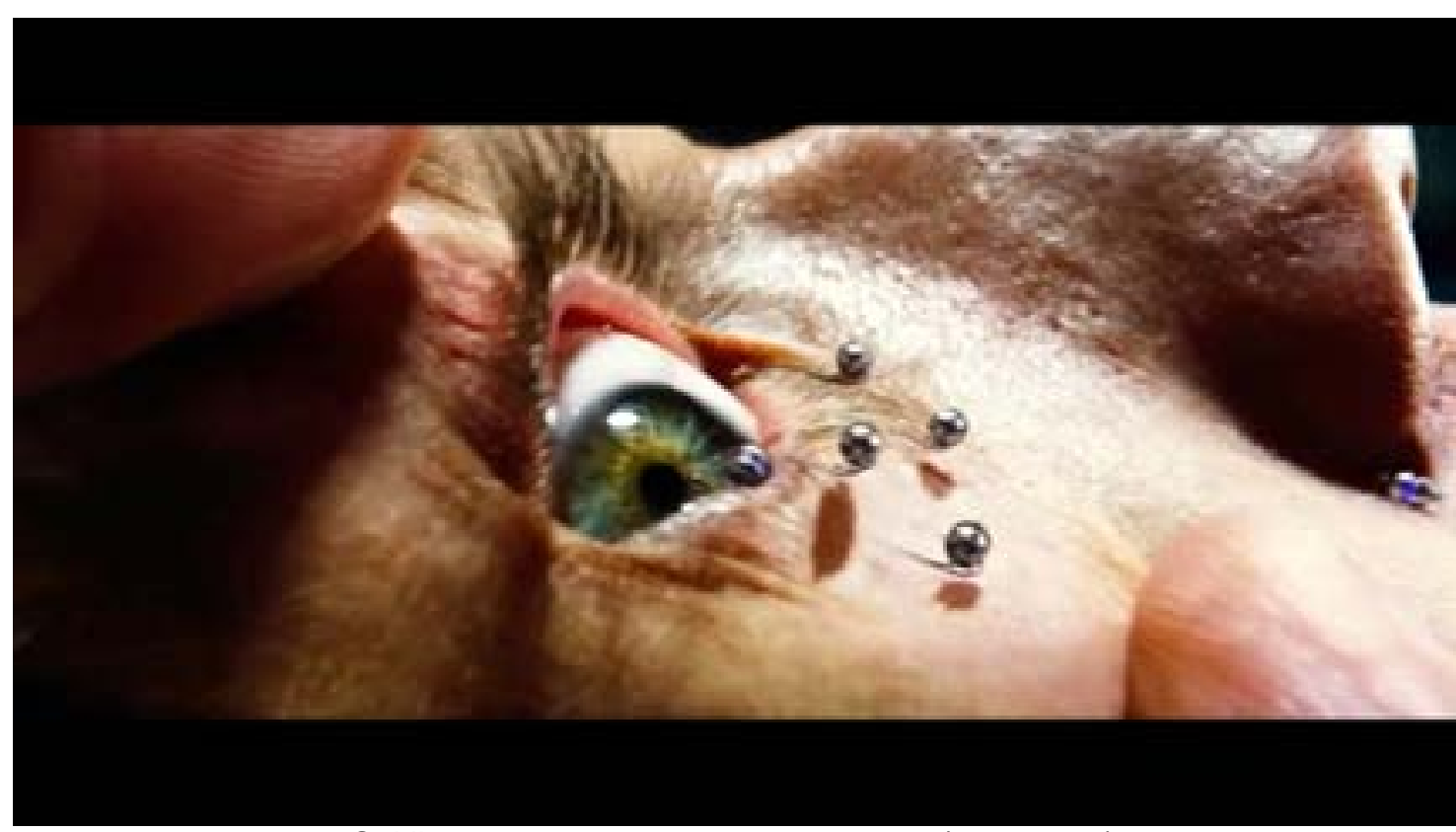

Şekil 20. Klonlara Bedensel Müdahale (Bay, 2005) 
Filmin sonlarına doğru, Lincoln-6-Echo ve Jordan-2-Delta'nın tesisten kaçış yolunu bularak dış dünyaya ulaşmasıyla, sistemde arızanın oluştuğu gerekçesiyle kusurlu olarak üretildiği düşünülen dört serinin imhasına karar verilmektedir. Yetişkin klonlar için 'Ada'ya gönderilecekleri' vaadiyle toplu bir çekiliş düzenlenmekte (Şekil 21), cenin aşamasında olan klonların ise yaşam üniteleri doğrudan yok edilmektedir (Şekil 22).

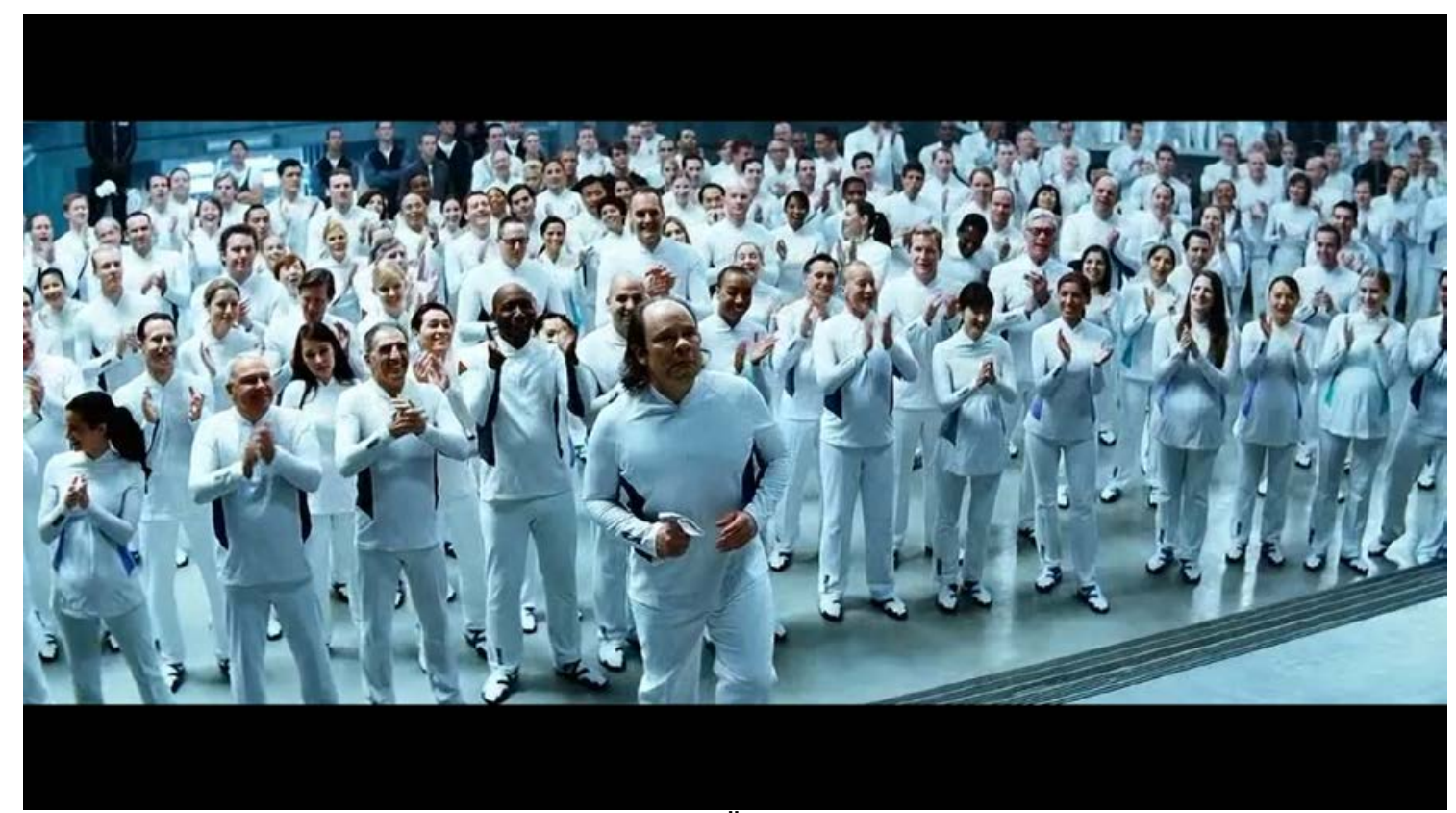

Şekil 21. Yetişkin Klonların Ada'ya Gitmek Üzere Yapılan Toplu Çekiliş Anı (Bay, 2005)

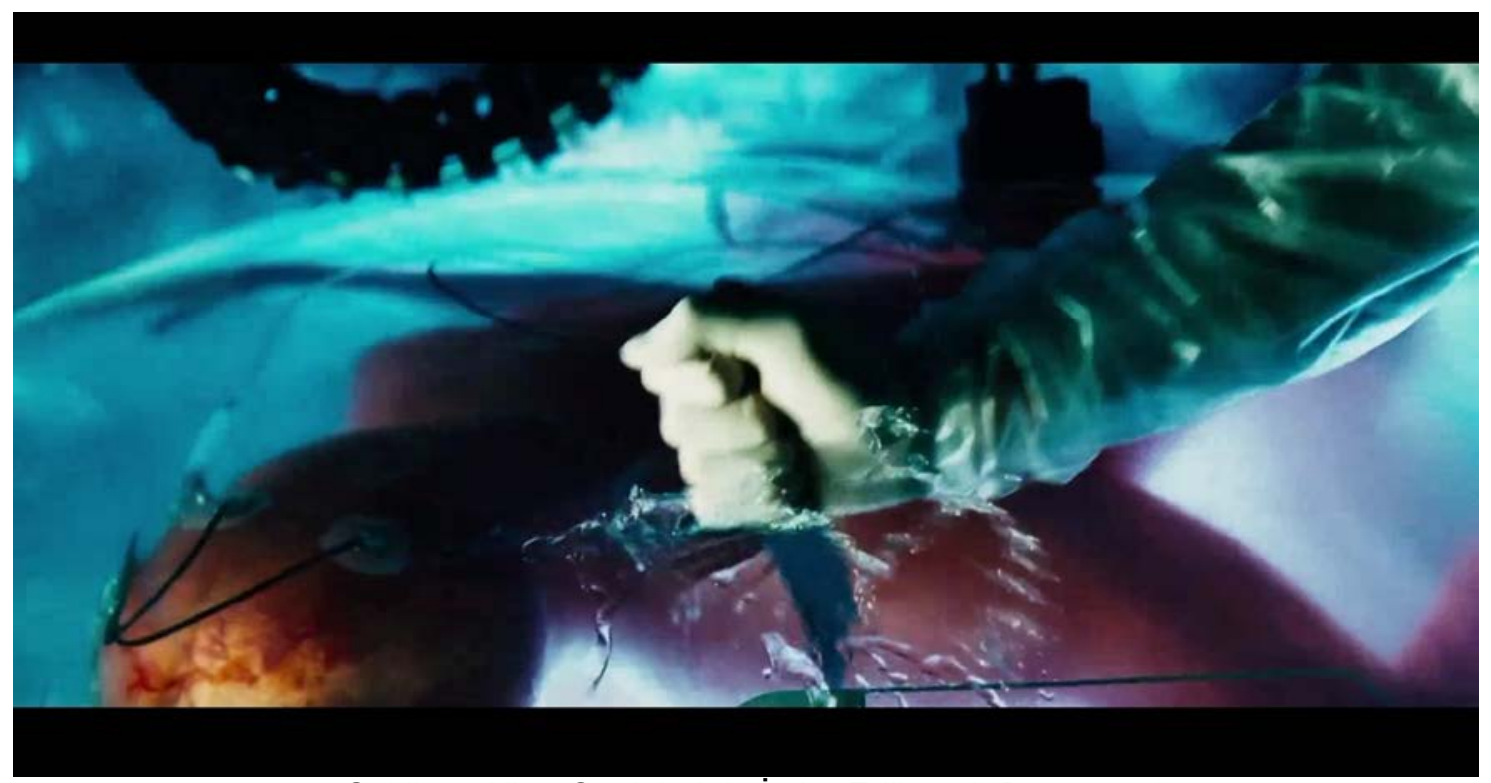

Şekil 22. Klon Ceninlerinin Imha Edilmesi (Bay, 2005)

Filmin bitiş sahnesinde, tesisten kaçmış olan Lincoln-6-Echo geri dönerek klonların gerçek dünyayı görmesini sağlamak için sistemin kontrol merkezine girerek şalteri kapatmaktadır. Sistemin çökmesiyle yer altında bulunan tesis zarar görmekte ve klonlar toplanma mekanına giren ışığı takip ederek yeryüzüne çıkış yolunu bulmaktadır (Şekil 23). Klonlar böylece doğdukları günden itibaren gerçek olduğunu düşündükleri dünyanın bir kurgudan ibaret olduğunu fark ederek gerçek dünyaya ulaşmaktadırlar (Şekil 24-26). 


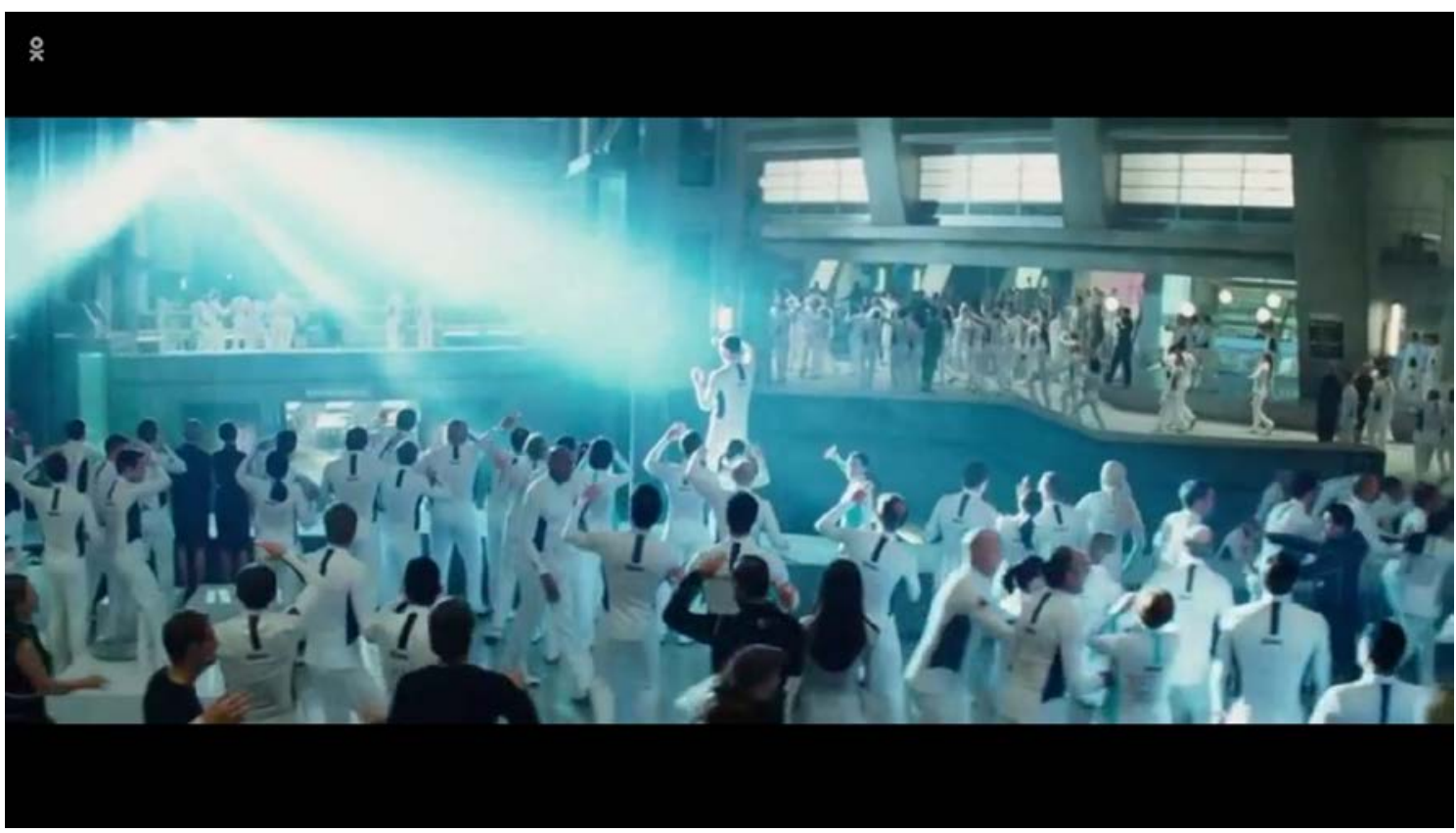

Şekil 23. Tesise Giren Gerçek Gün Işığını Fark Eden Klonlar (Bay, 2005)
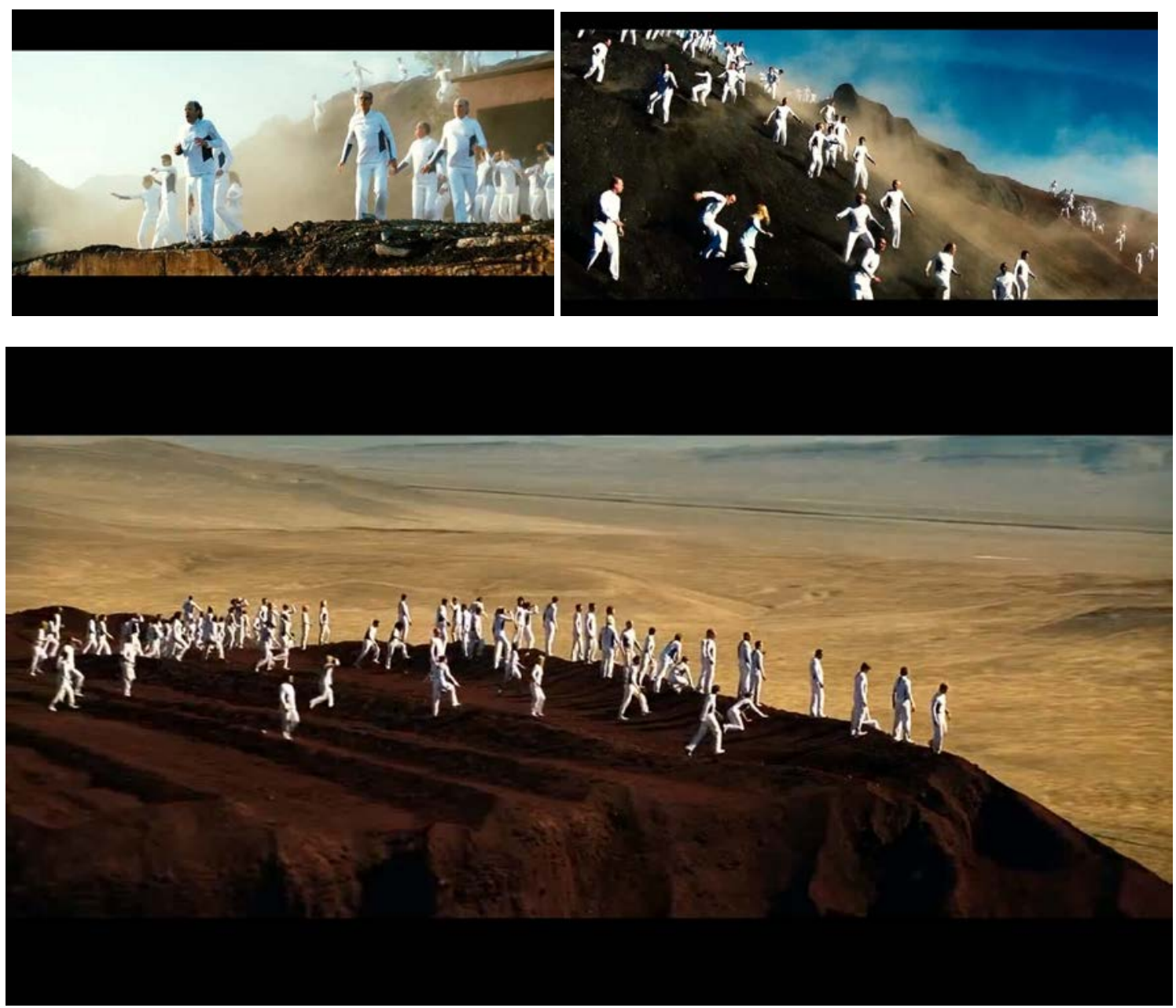

Şekil 24-26. Klonların Tesisten Gerçek Dünyaya Çıkış Anları (Bay, 2005) 


\section{DEĞERLENDIRME}

Ada filmi, tasvir etmiş olduğu distopik sistemde günümüz toplumlarında mevcut olan çifte standartlara dikkati çekmekte, sistemin herkese eşit davranmadığı, gözetim ve kontrol mekanizmalarının kişiler ve sınıflar arasında ayrımlar yaptığına ve gelecekte bu ayırımların giderek büyüyebileceği uyarısında bulunmaktadır. Film 2019 Yılının kentini ve yaşam tarzını distopik öğelerle yansıtmaktadır. Kaotik bir kentsel mekana karşılık ideal olarak tariflenen tek tipleştirilmiş iç mekanlar ile aslında mekânsal kurguda da bir çelişki gözlenmektedir.

Geçmiş ve geleceğin olmadığı sonsuz bir "şuan" içerisinde hapsolmuş klonlar için zaman anlamını yitirmiştir. Tek tip bir zaman çizelgesinde kontrol ve gözetim altında birbirinin aynı fiziksel ve sosyal şartlarda aynı hayatları yaşamaya mahkum bırakılmaktadırlar.

Filmde geleceğin kapitalizm sistemi ve genetik mühendisliğinin, insanların nesneleştirilmesinde nasıl kullanılabileceğine dair eleştiriler bulunmaktadır. Klonlamayla ilgili bu uygulamaların toplumsal hayat üzerinde yaratabileceği etkiler ve üretilen canlıların haklarının ne olacağı konusuna dikkati çekmektedir. Kendilerini birey olarak gören ve eşitlikçi bir ortamda yaşadıklarına inanan klonların bedenleri asılında insanlar için organik birer meta haline gelmişlerdir.

Doğası gereği eşitliğe dayalı olmayan kapitalizm sisteminin, bu yeni teknikler ve uygulamaları kullanarak kendine yeni pazarlar üretmek ve yeni üstün sınıflar yaratmak uğruna insanların bu sistem için bir basamak ya da sarf malzemesi olarak kullanılabileceğinin örneği görülmektedir.

\section{KAYNAKLAR}

Alver, Köksal, "Ütopya: Mekan ve Kentin İdeal Formu", Sosyoloji Dergisi 18, 2009, s.139-153.

Başaran, Tuna, Soğuk Savaş Sonrası Bilimkurgu Sinemasında Distopik Sistemler ve Kontrol Mekanizmaları, Ankara Üniversitesi Sosyal Bilimler Enstitüsü, Radyo Televizyon Sinema Anabilim Dalı, Yüksek Lisans Tezi, Ankara 2007.

Bay, Michael (Yönetmen), The Island (Ada), California : Warner Bros Pictures, 2005.

Dear, Michael, "Between Architecture And Film", Architectural Design, NovemberDecember, Vol. 64, No. 11/12, 1994, s.8-15.

Ersümer, Oğuzhan, Bilimkurgu Sinemasında Cyberpunk, Altıkırkbeş Yayın, İstanbul 2013.

Gibson, William, Neuromancer, Çev.: Gonca Gülbey, Altıkırkbeş Yayınları, İstanbul 2012.

Heidegger, Martin, Varlık ve Zaman (Sein und Zeit), Çev.:Kaan H. Ökten, Agora Kitaplığı, İstanbul 2008.

Jameson, Fredric, Postmodernizm ya da Geç Kapitalizmin Kültürel Mantığı, Çev.: Nuri Plümer, 1. Basım, Yapı Kredi Yayınları, İstanbul 1994. 
Kınayoğlu, Gökhan, "Saniyede 24 Kare Ütopya", Arredamento Mimarlık, 11, 2001, s.80-82.

Kırış, İrem Maro, Uzak Yakın Mimarlık, 1. Basım, Tekin Yayınevi, İstanbul 2012.

Merleau-Ponty, Maurice, Phenomenology of Perception, Routledge \& Kegan Paul Ltd, London 1962.

Örs, Aslı Doğay, "Sinematografi ve Mimarlık", Arredamento Mimarlık, 11, 2001, s.7379.

Özakın, Özgür, "Bugünün Dünyasını Geleceğe Yansıtmak”, Arredamento Mimarlık, 11, 2001, s.82-87.

Polat, Nihal, Bir Kent Vizyonu Olarak Ütopya Olgusunun Sinema Bağlamında Analizi, Mimar Sinan Güzel Sanatlar Üniversitesi, Fen Bilimleri Enstitüsü, Şehir ve Bölge Planlama Anabilim Dalı Yüksek Lisans Tezi, İstanbul 2012.

Süalp, Z. Tül Akbal, Zaman Mekan Kuram ve Sinema, 1. Baskı, Bağlam Yayıncılık, İstanbul 2004.

Sütçü, Özcan Yılmaz, Gilles Deleuze'de Imge Hareketi Olarak Sinemanın Felsefesi, Es Yayınları, İstanbul 2005.

Tümer, Gürhan, Insan-Mekan İlişkileri ve Kafka, Sanat-Koop Yayınları, İzmir 1984.

URL-1: Istvan Csicsery - Ronay, Jr, "Cyberpunk and Neuromanticism", Missisipi Review, 1996, http://project.cyberpunk.ru/idb/cyberpunk_and_neuromanticism.html, (Erişim Tarihi: 6 Aralık 2016, saat: 23.23)

Ülker, Şafak Şilan, Mimarlık ve Sinema Ortak Alanında Zamansallık ve Gelecek Mekanları, Mimar Sinan Güzel Sanatlar Üniversitesi, Fen Bilimleri Enstitüsü, Mimarlık Anabilim Dalı, Yüksek Lisans Tezi, İstanbul 2011. 